from a Dutch research grant application that Herrmann had been asked to referee.

All three agencies are awaiting the outcome of the Berlin investigation and any possible trial before beginning their own steps to reclaim their money. Such a process could take years. If a trial were to prove that the pair were guilty of fraud, says Christoph Schneider, director for scientific and international affairs at the DFG, it would be a straightforward matter to sue for return of money.

Indeed, in the event of conviction, statesupported grant agencies and charities would be legally obliged to sue for return of grant money. But actually getting the money back would be fraught with difficulty, admits Bruno Zimmermann, the DFG section head who followed the case.

As grant agencies make contracts with institutions rather than individual researchers, the universities where the grant money was spent would presumably have to be sued first, he says. The legal responsibilities have yet to be sorted out, says Zimmermann.

Eser says he is "highly frustrated" with how slowly the case is moving, and is also worried that even if Herrmann's involvement is demonstrated, he may "get away without sanctions". Detlev Ganten, director of the Max Delbrück Centre in Berlin at which Herrmann and Brach worked for several years, is similarly angry at this possibility.

But not everyone is seeking retribution. Guido Adler, dean of medicine at Ulm University, points out that Herrmann is no longer working in academia, and believes that the most important issue is the work of a newly created task force, funded by the DFG, which will assess the scientific impact of the affair and set the record straight (see Box).

\title{
Task force set up to determine the damage
}

[MUNICH] Determined to assess the full extent of any scientific damage inflicted by the Herrmann and Brach affair (see opposite), the Deutsche Forschungsgemeinschaft (DFG), Germany's main university research funding agency, is funding a task force to pick through the details of around 500 publications that could have been affected

In April, Ulf Rapp, a professor of biology/ immunology at the University of Würzburg, was awarded a one-year grant to conduct the investigation. This will go considerably further than the investigation by a national scientific committee set up jointly last year by the three German institutes where Herrmann and Brach worked.

The national committee had identified 37 papers in which it concluded that data had either certainly or "most probably" been falsified, often by mixing computer-stored images from different experiments to create new figures.

Rapp's team are examining data and figures in all papers published by Herrmann and Brach, and also some published by former colleagues.

They will try to determine which data may have been fabricated or duplicated, and the origin of figures and their primary data. Co-authors on the papers have been asked for relevant information about how figures were created and who generated the data.

Rapp was selected because his field of research overlaps with that of Herrmann and Brach, and also because he returned to Germany in 1994 after 25 years abroad.

"The DFG wanted someone independent to head the task force, and because of my absence I was not part of a local network," Rapp says. The investigation's results will be presented to the DFG next year and may be used in court proceedings. A.A.
Meanwhile Herrmann, who now works in a private medical practice Munich, continues to deny any involvement in misconduct, and sees the failure to bring charges against him as proof of his innocence. He says he is a victim of press harassment which "has harmed my career and destroyed my family".

"Brach was the scientist in the lab: my main and only job in the past ten years has been to care for patients", he says, contradicting the views of many former colleagues that he has always been more of a lab researcher than a clinician. "Now I just want to be left in peace to build up some sort of future."
He could well achieve his goal. The German Chambers of Physicians, which regulate the medical profession, is informed automatically of court convictions - but does not require doctors on their lists to submit details of criminal investigations.

And if Brach is indeed living in New York, she may well avoid a trial because Germany has only an extradition agreement - under which cases are negotiated individually, and the outcome often depends on the severity of the charges - rather than an extradition treaty, in which extradition is automatic on request.

Alison Abbott
IVF drugs cause superovulation, resulting in numerous excess oocytes. Since these cannot be stored frozen, but embryos can, the oocytes are fertilized. France has tens of thousands of these excess embryos in storage. At present, the law only allows for couples who have decided not to conserve their surplus embryos to donate them to a sterile couple, or for unwanted embryos to be destroyed after five years in storage.

Critics such as Kahn argue that it is hypocritical to allow the destruction of surplus embryos but to ban their use for research. "They would be destroyed in any case," he says.

A spokesperson for Jean-François Mattei - a physician who opposes human embryo research and, as a member of parliament (Démocracie Liberale, Bouches-du-Rhône), was the main architect of France's bioethics legislation - agrees that the fate of surplus embryos has raised difficult questions.

But he argues that recent technical

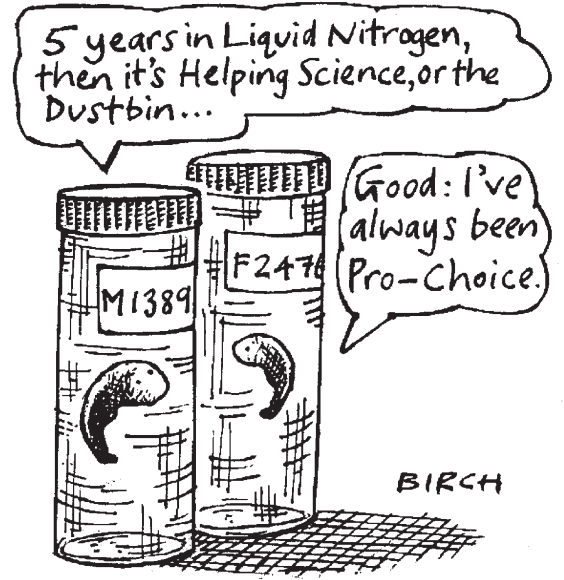

progress in freezing oocytes means that surplus embryos will soon no longer be produced. Kahn argues that this is still "far off", and that the committee's recommendations only relate to the contemporary situation.

Pressure for relaxing the embryo research ban also comes from many scientists within the research agencies. The Centre National de la Recherche Scientifique (CNRS), for example, is discussing with the government how the bioethics laws should be revised to take more account of researchers' other concerns - such as the copious paperwork required for even the most innocuous human genetics research.

Scientists are particularly keen to see the law on embryo research liberalized in order to explore the therapeutic opportunities opened up by progress in cloning and the creation of embryonic stem-cell technologies. The national bioethics committee has already argued that the potential of the latter area is such that it requires a dispensation from the current ban (see Nature 387, 218; 1997).

The current Socialist government is, in principle, likely to be more sympathetic to researchers' needs than its conservative predecessors. 